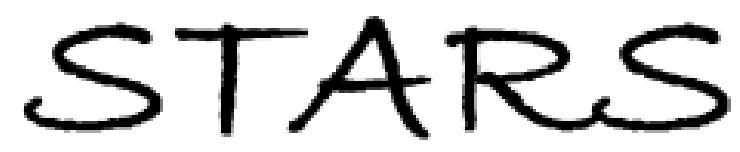

University of Central Florida

STARS

$1-1-2002$

\title{
Investigation of recycled concrete made with limestone aggregate for a base course in flexible pavement
}

Shiou-San Kuo

University of Central Florida

Hesham S. Mahgoub

University of Central Florida

Abdenour Nazef

University of Central Florida

Find similar works at: https://stars.library.ucf.edu/facultybib2000

University of Central Florida Libraries http://library.ucf.edu

This Article is brought to you for free and open access by the Faculty Bibliography at STARS. It has been accepted for inclusion in Faculty Bibliography 2000s by an authorized administrator of STARS. For more information, please contactSTARS@ucf.edu.

\section{Recommended Citation}

Kuo, Shiou-San; Mahgoub, Hesham S.; and Nazef, Abdenour, "Investigation of recycled concrete made with limestone aggregate for a base course in flexible pavement" (2002). Faculty Bibliography 2000 s. 3302.

https://stars.library.ucf.edu/facultybib2000/3302

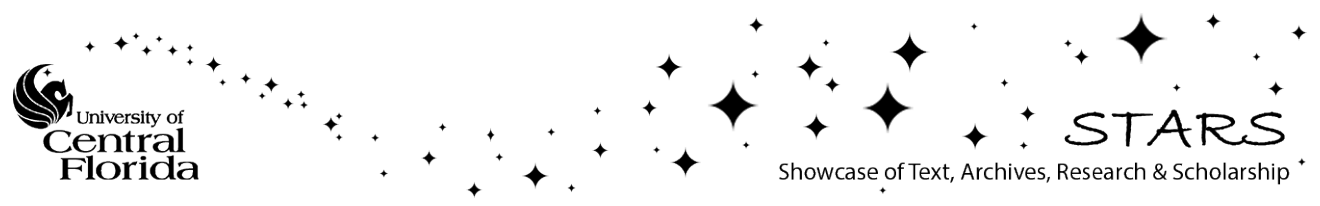




\title{
Investigation of Recycled Concrete Made with Limestone Aggregate for a Base Course in Flexible Pavement
}

\author{
Shiou-San Kuo, Hesham S. Mahgoub, and Abdenour Nazef
}

\begin{abstract}
The research objectives were to investigate the feasibility of using recycled concrete aggregate (RCA) as a base course material in asphalt pavement, to evaluate the physical properties of RCA, and to develop practical and reliable guidelines and specifications. The tasks included literature review, sample collection, laboratory testing, accelerated performance testing and pavement distresses monitoring, falling weight deflectometer (FWD) test, theoretical analysis of pavement, and development of guidelines and specifications for the use of Florida RCA. Three test sections of asphalt pavement were constructed at the University of Central Florida's circular accelerated test track. Two sections of different thicknesses were constructed with RCA base and one section with limerock (LR) base. A total of 362,198 load repetitions were applied to the test sections. This is equal to 811,324 repetitions of the 18-kip (80-kN) equivalent single-axle load. The pavement distresses of rutting, cracking, and settlement were monitored during the course of the performance testing. The FWD test was performed on the pavement test sections to backcalculate the in situ resilient moduli of RCA and LR for theoretical analysis of life expectancy. The findings support the hypothesis that RCA can be used effectively as a base course when appropriate quality control techniques are used. On the basis of the information obtained, a set of specifications for the use of RCA as a base course in flexible pavements was developed.
\end{abstract}

The deposition of demolished concrete from old structures in landfills is currently an unfavorable strategy because of the declining availability of disposal space, the increasing cost of disposal, and other environmental concerns. Recycling of old structures as construction materials is a viable alternative. A survey of various U.S. highway agencies showed that many states recognize the great potential for the use of recycled concrete aggregate (RCA) in highway construction. Currently, RCA is limited to use in pavement bases, shoulder concrete, porous granular fill, and as a portion of the aggregates in new concrete pavement. If RCA is adopted for extensive use as a base course material, replacing the natural aggregates currently used in pavement construction, then the physical and mechanical properties of RCA must be well understood, and guidelines for applications must be established. The performance of RCA used in pavement must be ensured to be better than or equal to the performance of virgin aggregates.

The objectives of this research study are $(a)$ to investigate the feasibility of using RCA as a base course material in asphalt pavement, (b) to evaluate the physical properties of RCA, and (c) to develop practical and reliable guidelines and specifications. The tasks included in this study are literature review, sample collection, laboratory test-

S.-S. Kuo and H. S. Mahgoub, Department of Civil and Environmental Engineering, University of Central Florida, Orlando, FL 32816. A. Nazef, State Materials Office, Florida Department of Transportation, Gainesville, FL 32609. ing, accelerated performance testing and pavement distresses monitoring, deflection testing, theoretical analysis of pavement test sections, and development of guidelines and specifications.

\section{RCA ORIGIN}

RCA is fundamentally a material obtained from the demolition of old concrete structures such as buildings, roads, runways, and other structures. By definition, RCA is a material composed by nearly $60 \%$ to $75 \%$ of high-quality, well-graded aggregates bonded by a hardened cementable paste. RCA may include $10 \%$ to $30 \%$ of subbase soil materials and asphalt from either the shoulder or composite pavement. RCA must not contain harmful impurities such as lead and asbestos, and it must not react with either cement or reinforcement when it is used for concrete admixtures.

\section{PROCESSING TECHNIQUES}

A basic requirement for producing high-quality recycled aggregate is the selection of the material entering the preparation process. This presumes a well-organized acceptance and storage of incoming material as well as effective material management. One of the techniques used to prepare RCA is the use of picking belts that enable the separation of large substances before raw material with particle sizes greater than 1.77 in. ( $45 \mathrm{~mm}$ ) can be transformed into granulate, mainly by impact crushers.

\section{RCA PROPERTIES}

Numerous tests have been carried out to determine the properties of recycled aggregates derived from waste concrete. RCA particles typically have a coarser and more angular shape than do natural aggregates as a result of the crushing operations. RCA has a varying particle size distribution, depending on the crusher settings, and generally a lower density than virgin aggregates. One of the most distinctive features of RCA is the attached mortar and cement paste on the surface of the original gravels and the presence of contaminants.

The mechanical properties of compressive, tensile, shear strengths, and modulus of elasticity of RCA, were reported values in the range of $0 \%$ to $40 \%$ lower than those of comparable concretes containing virgin aggregates ( 1 ). Moreover, RCA exhibited higher water absorption, lower density, and similar durability under freeze-thaw conditions, whereas RCA alkalinity is considerably affected by its cement paste component. Cement paste consists of a series of calcium-aluminumsilicate compounds, including the highly alkaline calcium hydroxide that makes the RCA-water mixtures frequently surpass a pH of 11 . 
Table 1 shows typical mechanical properties of reclaimed concrete. In the table, the values of Los Angeles (LA) abrasion loss are somewhat higher than those of high-quality conventional aggregates, whereas magnesium sulfate soundness and California bearing ratio (CBR) values are comparable to those of conventional aggregates (2).

\section{PERFORMANCE OF RCA AS BASE OR SUBBASE FOR PAVEMENTS}

According to Chini and Kuo (3), 35 state agencies in the United States are currently using RCA in pavement construction. Although many studies on RCA as base course have been conducted, there are still some issues that need further investigation, such as tufa formation of RCA in granular base, long-term performance, and life-cycle cost. Chini and Kuo describe in detail the aggregate properties that influence the functions of pavement base courses (3).

\section{CURRENT SPECIFICATIONS}

Currently, there are 26 states that allow the use of reclaimed portland cement concrete as a base course aggregate, whereas 4 states allow the use of RCA as a subbase aggregate. Only 15 of the 28 state agencies that use RCA in base and subbase applications have standard specification guidelines for recycled aggregates $(3,4)$. A review of international standards for the use of RCA in Australia, Belgium, Canada, France, Japan, Netherlands, Spain, and the United Kingdom shows that most of the specifications emphasize gradation, abrasion loss, and impurities $(5,6)$.

\section{RCA SAMPLING}

To adequately evaluate the quality of RCA in this study, a concrete recycling plant from six of the seven Florida districts was scheduled for monthly sampling for a period of 6 months. A two-person crew collected RCA materials from districts following the Florida Department of Transportation (DOT) sampling procedures (FM 1-T 002). At completion of the sampling, the materials were immediately distributed to the laboratories at the Florida DOT State Materials Office in Gainesville, the Florida DOT District 5 in Deland, and the University of Central Florida (UCF) test facility in Orlando.

\section{LABORATORY TESTING AND RESULTS}

The laboratory tests conducted in this project included aggregate gradation, limerock bearing ratio (LBR), LA abrasion, soundness, sand equivalent, heavy metals, modified Proctor compaction, hydraulic conductivity, and impurity contents. In addition, the asphalt pavement test sections made with the two RCA and one limerock base courses were tested at the UCF circular accelerated test track (CATT) for evaluation of fatigue and rutting distresses. All laboratory test methods were based on the ASTM and Florida DOT testing specifications.

\section{Particle Size Distribution [Gradation)}

The results of gradation from all samples collected revealed that the RCA gradation average from every sieve size meets the Florida DOT specification for graded aggregate base material. However, at 90\% intervals (minimum and maximum) from sieve sizes of $19 \mathrm{~mm}$

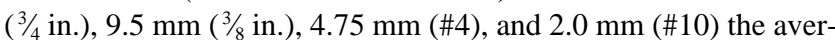
age gradation slightly fell outside of Florida DOT specifications because the standard deviations for these four sieve sizes are relatively high. As the test results show, it seems that those four sieve sizes may become more critical for recycled materials. The average gradations of all collected samples are plotted in Figure 1.

\section{Limerock Bearing Ratio}

Similar to the CBR test, the Florida DOT LBR test (FM5-515) consists of using a $10-\mathrm{lb}(0.0445-\mathrm{kN})$ piston hammer dropped from a height of $18 \mathrm{in} .(45.7 \mathrm{~cm})$ onto a compacted sample of base material. Load readings are recorded for each $0.01 \mathrm{in} .(0.25 \mathrm{~mm})$ of penetration. From the LBR test results shown in Table 2, it appears that the recycled concrete materials consistently provide very high LBR values with only a few outliers, particularly from District 6 . The average LBR for District 6 was only 80 because of the large amount of foreign materials presented in the samples. The overall LBR average of 181.71 surpasses the 100 requirement of Florida DOT Specification Section 204.

\section{Los Angeles Abrasion Test}

The Los Angeles (LA) abrasion test is a measure of degradation of mineral aggregate particles smaller than $1 \frac{1}{2}$ in. $(37.5 \mathrm{~mm})$ of standard grading resulting from a combination of actions including abrasion, impact, and grinding occurring in a rotating steel drum containing a number of steel spheres.

The results of the LA abrasion test from all samples are presented in Table 3. The Florida DOT LA abrasion loss of natural aggregates used for base courses is specified to be less than $45 \%$. The average values of LA abrasion loss for the RCA samples are in the range of $41.62 \%$ to $47.60 \%$, as shown in Table 3 .

TABLE 1 Typical Mechanical Properties of Reclaimed Concrete Material

\begin{tabular}{|l|c|}
\hline \multicolumn{1}{|c|}{ Property } & Value (\%) \\
\hline $\begin{array}{l}\text { Los Angeles Abrasion Loss (ASTM C131) } \\
\text { - Coarse particles }\end{array}$ & $20-45$ \\
\hline $\begin{array}{l}\text { Magnesium Sulfate Soundness Loss (ASTM C88) } \\
\text { - Coarse particles }\end{array}$ & $\begin{array}{c}4 \text { or less } \\
\text { - Fine particles }\end{array}$ \\
\hline California Bearing Ratio (CBR)*
\end{tabular}

*Typical CBR value for crushed limestone is 100 percent. SOURCE: Federal Highway Administration (2). 


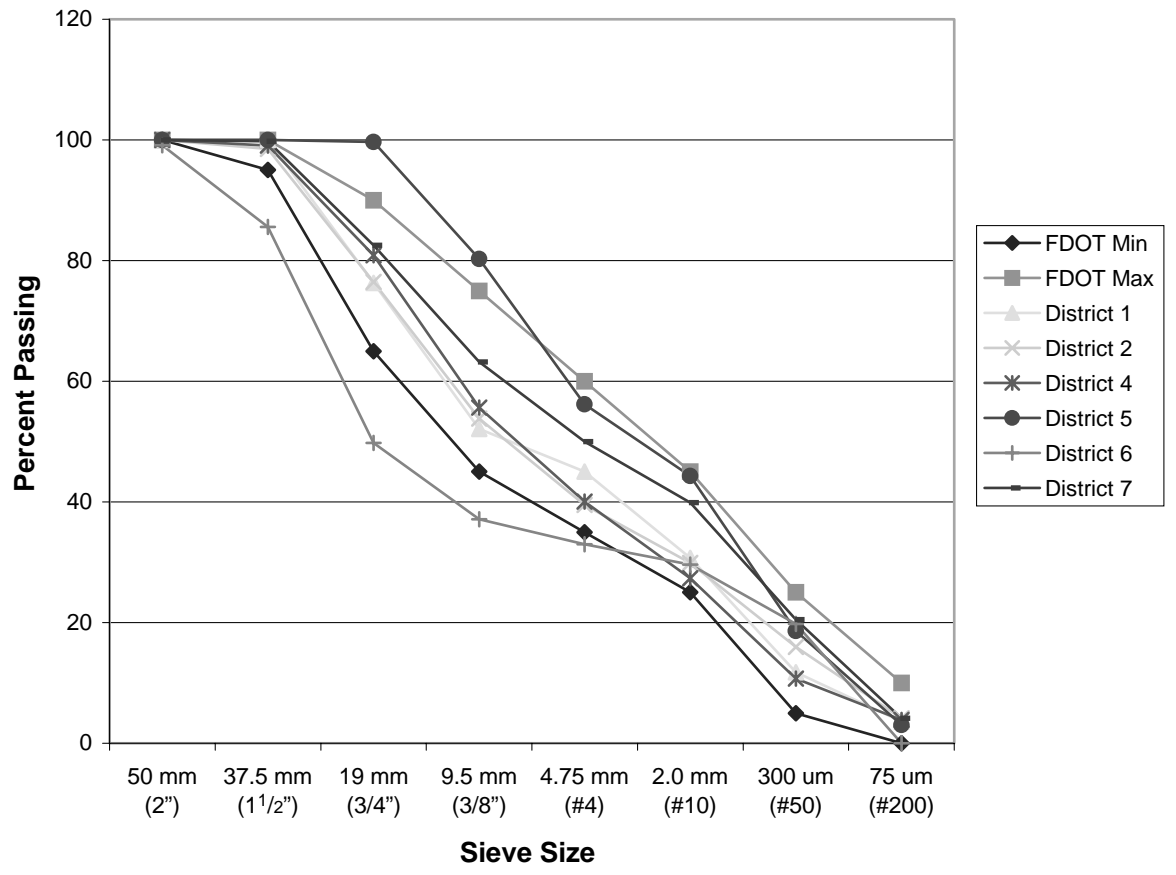

FIGURE 1 Distribution of average particle size (FDOT = Florida Department of Transportation).

\section{Soundness}

Soundness is defined as the ability of the aggregate to withstand abrasion or crushing, or both. It is important to foresee the constructed pavement if the amount of fines will be generated from the coarse aggregates under the actions of roller and traffic loads. Soundness of aggregates can be tested by means of the sodium sulfate test, the LA abrasion test, and a combination of compaction and sieve tests. RCA generally has a higher loss of soundness due to its mortar content. Acceptable limits of $15 \%$ have been established by Florida DOT for graded aggregate bases. The average soundness loss is about $52 \%$, well above the Florida DOT specification. From a literature review it was seen that many countries and U.S. highway agencies have decided to waive the sodium sulfate test for recycled concrete aggregates. This is because the sodium sulfate will disintegrate the concrete aggregate during the test. Thus, the sodium sulfate test should be waived.

\section{Sand Equivalent}

The sand equivalent test is designed to measure the proportion of sand to clay within a sample. Florida DOT requires that aggregates passing through the $4.75-\mathrm{mm}$ sieve shall have a sand equivalent value of not less than $28 \%$. The RCA samples tested in this project were found to have sand equivalent values much higher than $28 \%$.

\section{Heavy Metals}

The heavy metal bracket includes cadmium, chromium, aluminum, nickel, iron, zinc, copper, and lead. Lead is the most critical of these metals. The Environmental Protection Agency (EPA) has set the limit on lead emissions to 5 parts per million (ppm). Table 4 lists the content of heavy metals tested in the samples collected from each district. The highest observed lead content of $12 \mathrm{ppm}$ from one sample

TABLE 2 Average LBR from Samples Collected at Various Districts

\begin{tabular}{|c|c|c|c|c|c|c|c|c|}
\hline $\begin{array}{c}\text { District } \\
\text { Designation }\end{array}$ & $\begin{array}{c}\text { Number of } \\
\text { Samples }\end{array}$ & \multicolumn{6}{|c|}{ Limerock Bearing Ratio (LBR) } & $\begin{array}{c}\text { Arithmetic } \\
\text { Mean }\end{array}$ \\
\hline 1 & 7 & $210.00 \quad 209.00$ & 188.00 & 260.00 & 197.00 & 237.00 & 251.00 & 221.71 \\
\hline 2 & 7 & $238.00 \quad 189.00$ & 79.00 & 109.00 & 150.00 & 217.00 & 238.00 & 174.29 \\
\hline 4 & 6 & $208.00 \quad 213.00$ & 90.00 & 208.00 & 143.00 & 317.00 & & 196.50 \\
\hline 5 & 6 & $158.00 \quad 175.00$ & 124.00 & 135.00 & 238.00 & 260.00 & & 181.67 \\
\hline 6 & 2 & $93.00 \quad 67.00$ & & & & & & 80.00 \\
\hline 7 & 6 & $168.00 \quad 122.00$ & 151.00 & 266.00 & 131.00 & 133.00 & & 161.83 \\
\hline UCF-CATT & 1 & 258.00 & & & & & & 258.00 \\
\hline \multirow[t]{3}{*}{ Total } & 35 & \multicolumn{2}{|c|}{ RCA Arithmetic Mean } & \multicolumn{3}{|l|}{ - } & \multicolumn{2}{|r|}{181.53} \\
\hline & & \multicolumn{2}{|c|}{ RCA Standard Deviation } & & & & & 61.31 \\
\hline & & \multicolumn{4}{|c|}{ RCA Arithmetic Mean Not Counting Outliers } & $\rightarrow$ & & 197.60 \\
\hline
\end{tabular}

NoтE: Outliers in italics. 
TABLE 3 LA Abrasion Loss of All Samples

\begin{tabular}{|ccccccccc|}
\hline Month & $\begin{array}{c}\text { FDOT Sect. } \\
\text { 204 }\end{array}$ & District & District & District & District & District & District & District \\
\hline December & $<45 \%$ & $44.53 \%$ & $42.75 \%$ & - & - & $41.62 \%$ & 42.23 & $44.46 \%$ \\
January & $<45 \%$ & $44.86 \%$ & $45.14 \% *$ & - & - & $42.67 \%$ & - & $43.71 \%$ \\
February & $<45 \%$ & $47.60 \% *$ & $44.40 \%$ & - & - & $43.35 \%$ & - & $44.59 \%$ \\
March & $<45 \%$ & $45.97 \% *$ & $43.12 \%$ & - & - & $42.79 \%$ & - & $47.13 \% *$ \\
April & $<45 \%$ & $46.16 \% *$ & $45.35 \% *$ & - & - & - & - & $44.61 \%$ \\
May & $<45 \%$ & $45.77 \% *$ & $43.71 \%$ & - & - & - & - & $45.18 \% *$ \\
June & $<45 \%$ & - & - & - & - & $42.97 \%$ & - & - \\
July & $<45 \%$ & - & - & 42.39 & - & $43.58 \%$ & - & - \\
August & $<45 \%$ & - & - & 43.42 & 41.83 & - & - & - \\
September & $<45 \%$ & - & - & 43.35 & 42.08 & - & - & - \\
\hline
\end{tabular}

TSR is a recycling plant.

*Does not meet FDOT Sect. 204 requirements.

at District 4 is clearly over the 5-ppm EPA limit. Because this is only one random sample, it may not represent the material characteristics of a full profile.

\section{Asbestos}

Because demolitions constitute approximately $10 \%$ of all reported asbestos-related activities according to EPA (7), state officials require that all buildings or structures must first be inspected and certified clear of asbestos before the demolition. Thus, the recycled concrete aggregates coming from demolished structures must be asbestos free. The laboratory analytical results indicated that asbestos fibers were not detected in any of the samples of crushed concrete analyzed.

\section{Modified Proctor Compaction Test}

The modified Proctor compaction test (T 180-74) was used to determine the optimum moisture and the maximum dry density of coarse aggregate. Before the samples were screened through a $19-\mathrm{mm}(3 / 4-\mathrm{in}$.) sieve, some aggregations were broken apart without crushing individual particles. All particles retained on the $19-\mathrm{mm}(3 / 4-$ in. $)$ sieve were discarded. Four specimens were made from each RCA sample, and the dry unit weight of each specimen was determined.

Simultaneous compaction tests of 30 and 31 samples were conducted at UCF and the Florida DOT District 5 laboratories, respectively. Although there are some variations in the results of maximum dry unit weight and the optimum moisture content from the two agencies, the arithmetic means of the dry unit weight $\left(113.8 \mathrm{lb} / \mathrm{ft}^{3}\right.$ of UCF versus $114.8 \mathrm{lb} / \mathrm{ft}^{3}$ of Florida DOT) and the moisture content (11.2\% of UCF versus $12.1 \%$ of Florida DOT) are very close.

\section{Hydraulic Conductivity (Permeability) Test}

Ideally, for good pavement performance, the permeability of granular base (aggregates) should be $0.283 \mathrm{ft} /$ day $\left(10^{-4} \mathrm{~cm} / \mathrm{s}\right)$ or greater $(8)$. The constant-head test was employed in this project. The 30 samples that were run on compaction test at UCF also underwent hydraulic conductivity testing. The average permeability value from all samples was $0.72 \mathrm{ft} /$ day $\left(2.54 \times 10^{-4} \mathrm{~cm} / \mathrm{s}\right)$. From the test results, it appears that most of the RCA material will meet the permeability requirement.

\section{Impurities}

Impurities (foreign material) present in RCA are one of the biggest concerns surrounding the use of this material in construction. To determine the amount of impurities, samples were passed through sieves to separate the aggregate into its different sizes, thus facilitating the removal of foreign materials by means of visual inspection. Impurities were classified into different categories such as wood chips and paper, plastics, steel, asphalt, and brick. The percentage by weight of foreign materials present contained in the December samples is plotted in Figure 2.

Generally, asphalt was the most predominant type of impurity. The average impurity content was $3.67 \%$ with District 6 included

TABLE 4 Content of Heavy Metals (in Parts Per Million]

\begin{tabular}{|c|c|c|c|c|c|c|c|c|}
\hline Month & Lead & Cadmium & Chromium & Aluminum & Nickel & Iron & Zinc & Copper \\
\hline District 1 & ND & ND & ND & $3700-5200$ & ND & $4100-18000$ & $0-140$ & ND \\
District 2 & ND & ND & $0-13$ & $2800-4408$ & $0-3$ & $3100-13000$ & $0-49$ & $0-22$ \\
District 4 & $0-12^{*}$ & ND & 16 & $2252-4600$ & $0-4$ & $2525-4800$ & $78-380$ & $0-15$ \\
District 5 & ND & ND & ND & $3600-5400$ & ND & $4600-7300$ & $24-120$ & ND \\
District 6 & ND & ND & $0-16$ & 5501 & $0-12$ & 4103 & 80 & 16 \\
District 7 & ND & ND & ND & $4100-5200$ & ND & $3700-5300$ & $0-380$ & ND \\
\hline
\end{tabular}

ND $=$ not detected.

*Lead content over 5 ppm in one sample. 


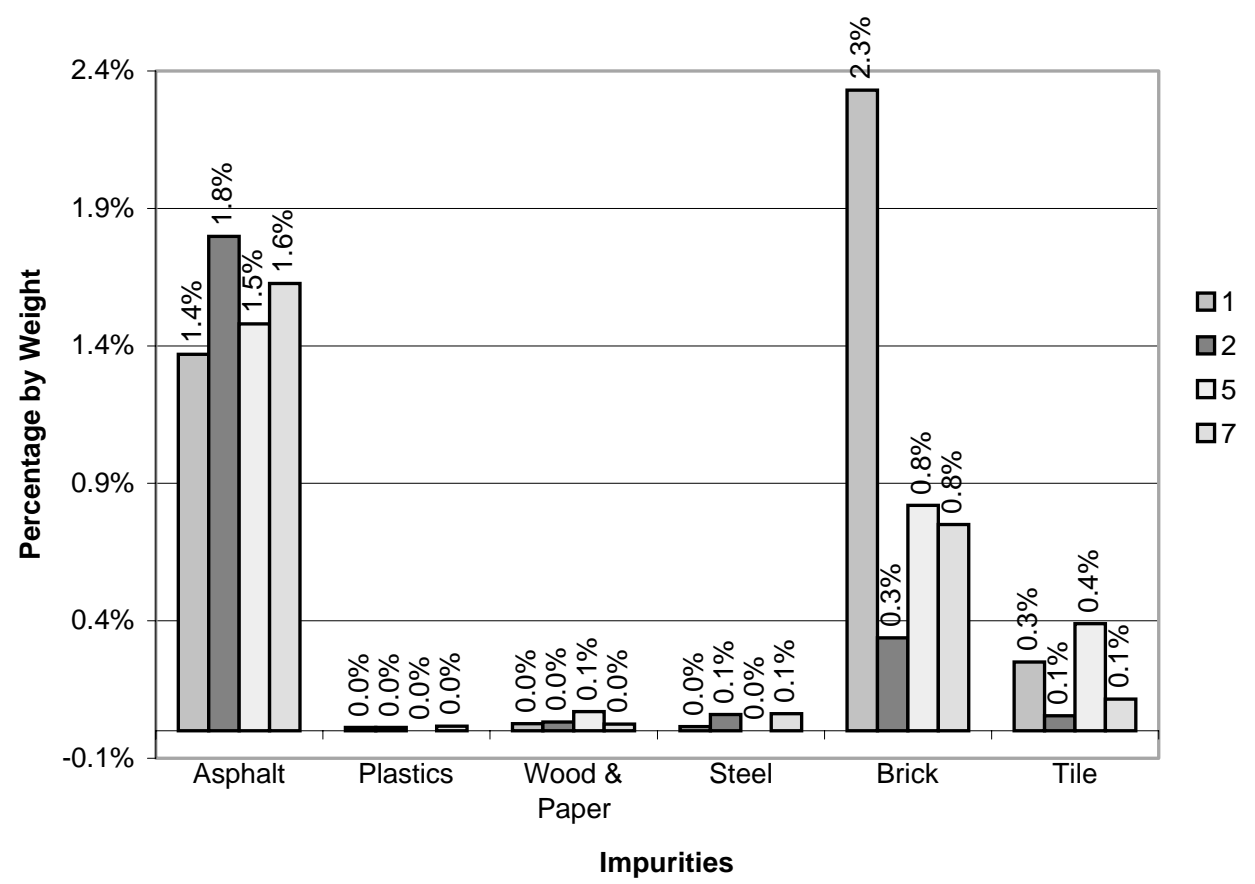

FIGURE 2 Percentage impurities by weight-Districts 1, 2, 5, and 7, December 1999.

and $1.99 \%$ without District 6 samples. Both of these percentages are considered to be a negligible amount.

\section{PERFORMANCE OF TEST SECTIONS}

\section{Test Sections Layout}

Figure 3 shows the layout of the test sections and the respective cross-section at UCF-CATT. The test track machine has three sets of dual truck tires that travel on a $6-\mathrm{ft}(1.8-\mathrm{m})$ wide pavement path guided by radial arms around a 50-ft (15.2-m) diameter of circular track. The loading on dual-wheel assemblies is capable of carrying up to $30,000 \mathrm{lb}(133.5 \mathrm{kN})$ per wheel. Three test sections on half of the track were deployed for the performance test of base courses in the flexible pavement system. Section 1 was constructed with an 8-in. (20.3-cm) thick RCA base, section 2 with a $10 \frac{1}{2}$-in. $(26.7-\mathrm{cm})$ thick RCA base, and section 3 with a 101/2-in. (26.7-cm) thick limerock base. All test sections were covered by 4 in. $(20.2 \mathrm{~cm})$ of Florida DOT-specified S-1 asphalt concrete.

The compaction of base materials was done in three equal lifts for all test sections. Each lift was compacted by a 1,000-lb (454-kg) vibrating compactor used by the contractor.

\section{Performance Test}

With the base courses in place, a 4-in. (10.2-cm) layer of hot-mix asphalt (HMA) was placed in two equal lifts over the base course. Each lift was compacted by a dual-steel-wheel roller compactor. The wheel load applied by the UCF-CATT machine represents the Florida legal axle load of $22,000 \mathrm{lb}(98 \mathrm{kN})$, or a half axle of $11,000 \mathrm{lb}(49 \mathrm{kN})$ with tire pressure of approximately $110 \mathrm{psi}(759 \mathrm{kPa})$. A total of 362,198 load repetitions were applied to the test sections.

The pavement distresses were monitored during the course of performance testing. No surface rutting was measured in any of the test sections. However, a total of 16 transverse cracks and one longitudinal crack appeared along the wheel path in the limerock section. No cracks were observed in either RCA test section.

\section{THEORETICAL ANALYSIS}

\section{Falling Weight Deflectometer Test}

The FWD test was conducted at the UCF-CATT test sections before the performance test. The transducers were located at $8 \mathrm{in} .(20.32 \mathrm{~cm})$, 12 in. $(30.48 \mathrm{~cm}), 18$ in. $(45.72 \mathrm{~cm}), 24$ in. $(60.96 \mathrm{~cm}), 36 \mathrm{in.}$ $(91.44 \mathrm{~cm})$, and 60 in. $(152.4 \mathrm{~cm})$, respectively, from the center. The magnitudes of the load that were measured by the load cell ranged from $79 \mathrm{psi}(550 \mathrm{kPa})$ to $134 \mathrm{psi}(925 \mathrm{kPa})$.

The results of the FWD test were used to plot deflection basins for each test section. Figures 4 through 6 show the deflection basins for test sections 1, 2, and 3, respectively. Every deflection measured in the limerock test section was significantly higher than those in the RCA test sections, whereas the deflections between the two RCA test sections show practically no difference.

\section{Backcalculation of In Situ Elastic Modulus with KENLAYER}

The KENLAYER program was employed to backcalculate the modulus of elasticity of the RCA base material by using the load-deflection data obtained from the FWD test (9). The resilient modulus of the HMA surface course was determined from the laboratory cyclic load testing. An average modulus of $380,000 \mathrm{psi}(55,112 \mathrm{kPa})$ is used for the input of surface course in KENLAYER. The resulting moduli of the base and subgrade layers as bonded pavement components for the best fit of deflection basins were $E_{\mathrm{RCA}}=195,000 \mathrm{psi}(28,281 \mathrm{kPa})$, $E_{\mathrm{LR}}=60,000 \mathrm{psi}(8,702 \mathrm{kPa})$, and $E_{\mathrm{Subg}}=30,000 \mathrm{psi}(4,350 \mathrm{kPa})$. The moduli of RCA and limerock are comparable to the test results of test 

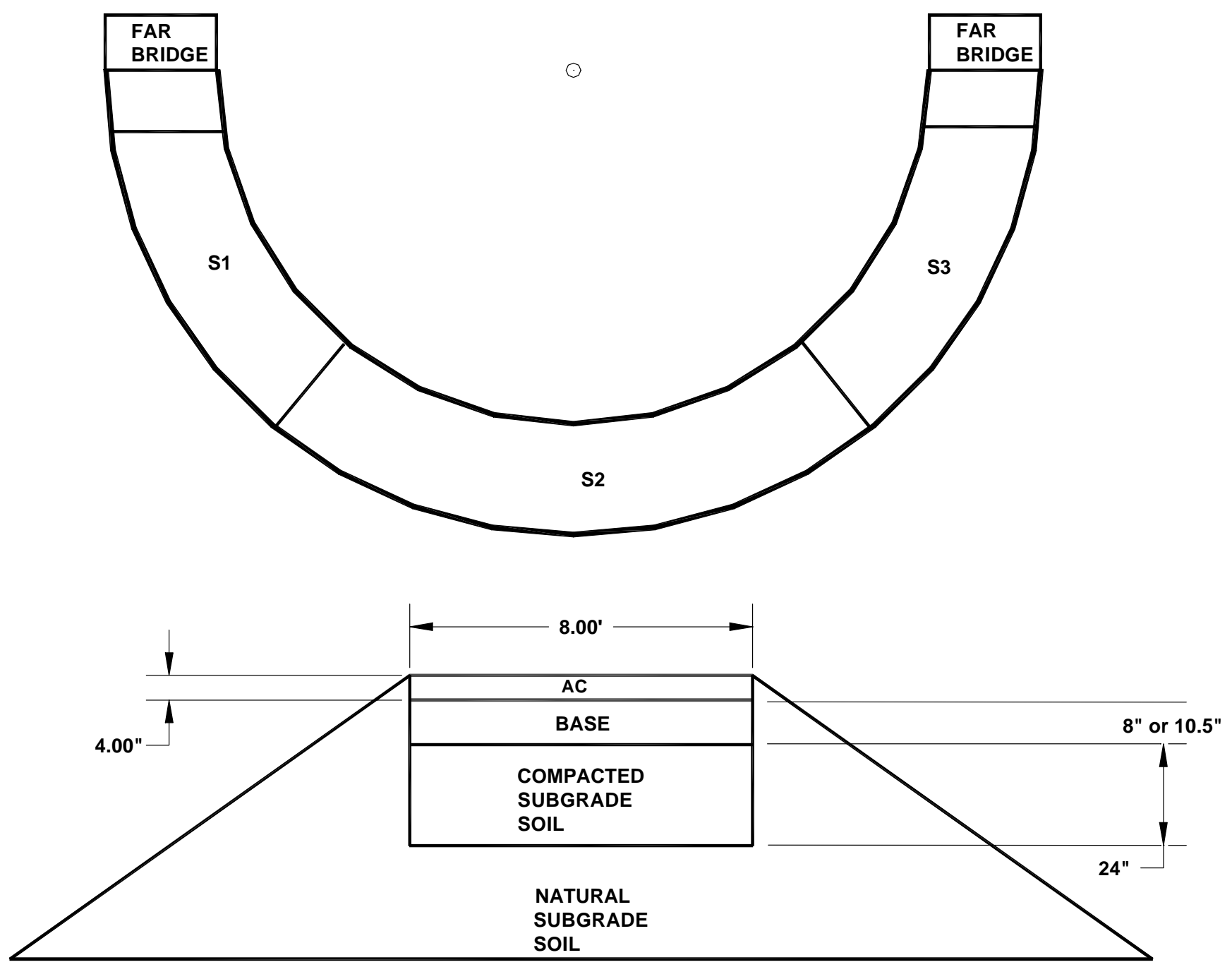

\begin{tabular}{|c|c|c|}
\hline Section & Base Course & Thickness (inch) \\
\hline 1 & RCA & 8.0 \\
2 & RCA & 10.5 \\
3 & Limerock & 10.5 \\
\hline All Sections & Compacted Subgrade Soil & 24 \\
\hline
\end{tabular}

FIGURE 3 Test section layout and cross-section ( $A C=$ asphalt concrete).

pits conducted at the Florida DOT Material Office. Figure 7 presents a sample of the best-fit curves from the FWD deflection basins and the KENLAYER program.

\section{Failure Criteria of Flexible Pavements}

The theoretical failure criteria of flexible pavements are fatigue cracking and permanent deflection (rutting). The equations of fatigue and rutting criteria as proposed by the Asphalt Institute and other agencies are as follows $(10)$ :

$$
\begin{aligned}
& N_{f}=f_{1}^{*}\left(\epsilon_{t}\right)^{-f_{2}}\left(E_{1}\right)^{-f_{3}} \\
& N_{d}=f_{4}^{*}\left(\epsilon_{c}\right)^{-f_{5}}
\end{aligned}
$$

where

$N_{f}=$ number of allowable load repetitions to prevent fatigue,

$\epsilon_{t}=$ tensile strain at the bottom of the asphalt layer,

$E_{1}=$ elastic modulus of asphalt concrete,

$f_{1}, f_{2}, f_{3}=$ constants determined from laboratory fatigue tests, 


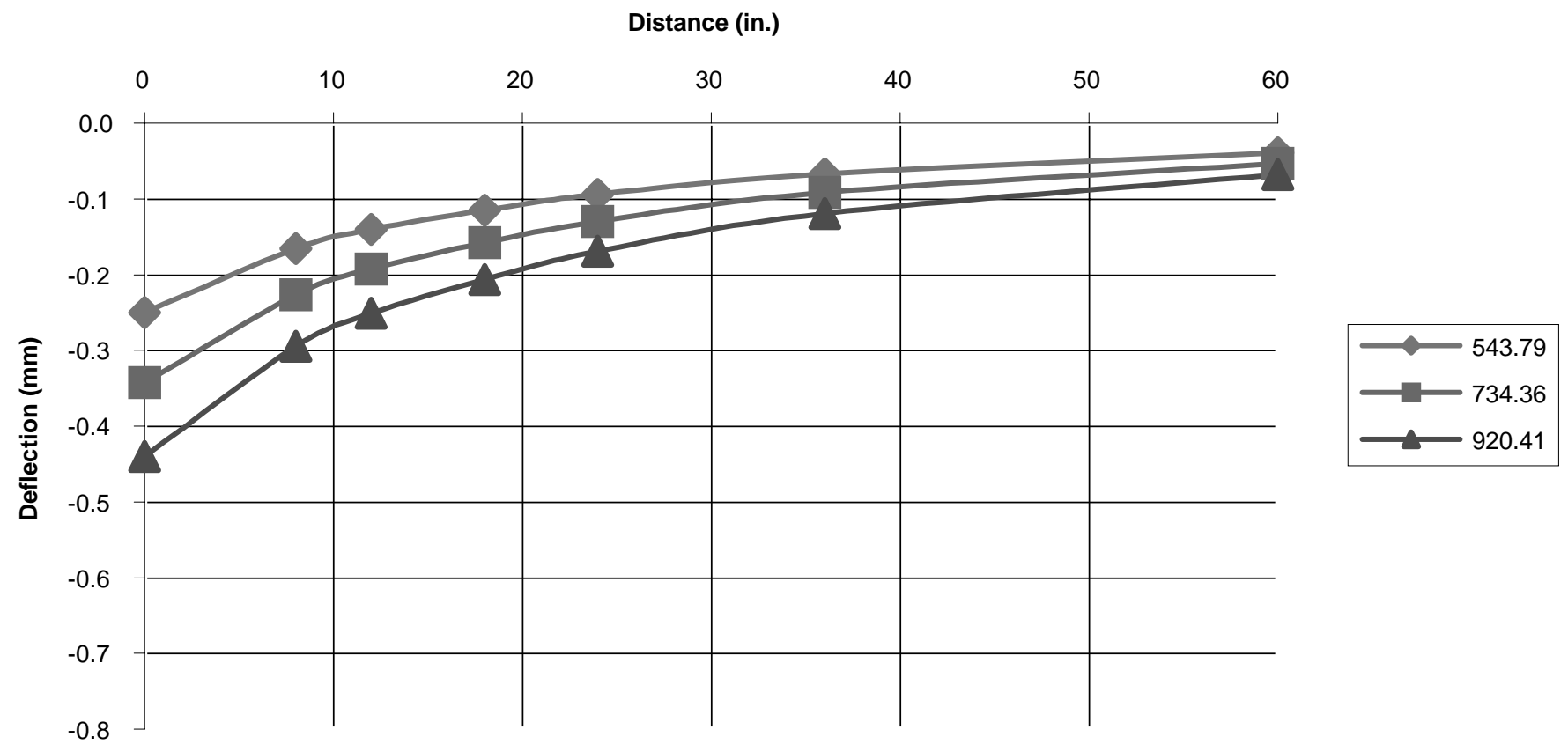

FIGURE 4 Average deflections for an 8.0-in. RCA layer, Section 1.

$N_{d}=$ number of allowable load repetitions to limit permanent deformation,

$\boldsymbol{\epsilon}_{c}=$ compressive strain on top of subgrade, and

$f_{4}, f_{5}=$ constants determined from road test or road performance.

By the transference of the known input data of wheel load, tire contact area, layer dimensions, and modulus of each layer to the KENLAYER program, the tensile strain at the bottom of the asphalt layer and the compressive strain on the top of subgrade were calculated. $N_{f}$ and $N_{d}$ for RCA and LR were then calculated as
$N_{f}=39 \times 10^{6}, N_{d}=1.8 \times 10^{6}($ RCA section 1$)$,

$N_{f}=45 \times 10^{6}, N_{d}=6.9 \times 10^{6}$ (RCA section 2$)$, and

$N_{f}=9.2 \times 10^{5}, N_{d}=1.3 \times 10^{6}($ LR section 3$)$.

\section{Life Expectancy Analysis}

For the accelerated testing, the machine applied a dual-wheel load of 11 kips $(49 \mathrm{kN})$. This dual-wheel loading, which is equivalent to a 22-kip (98-kN) single-axle load, is heavier than the standard 18-kip

Distance (in.)
0
10
20
30
40
50
60
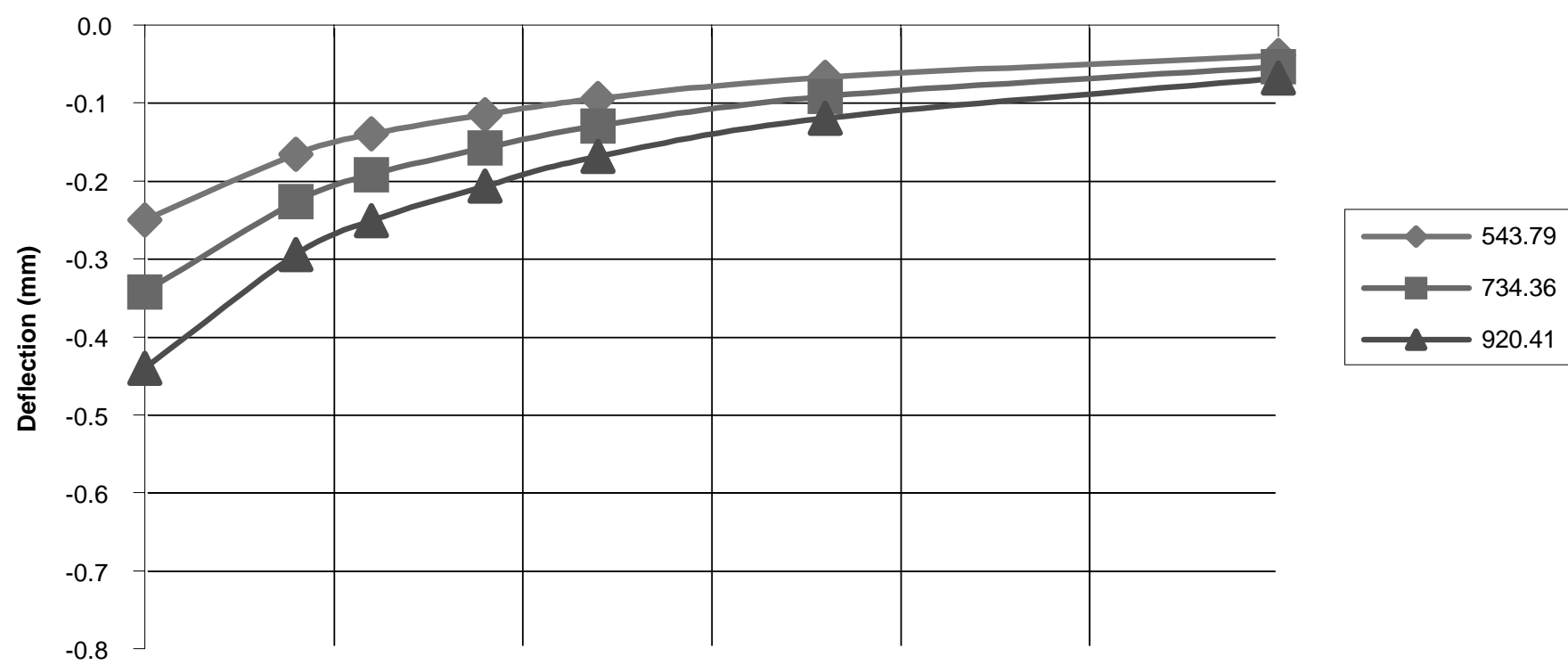

FIGURE 5 Average deflections for a 10.5-in. RCA layer, Section 2. 


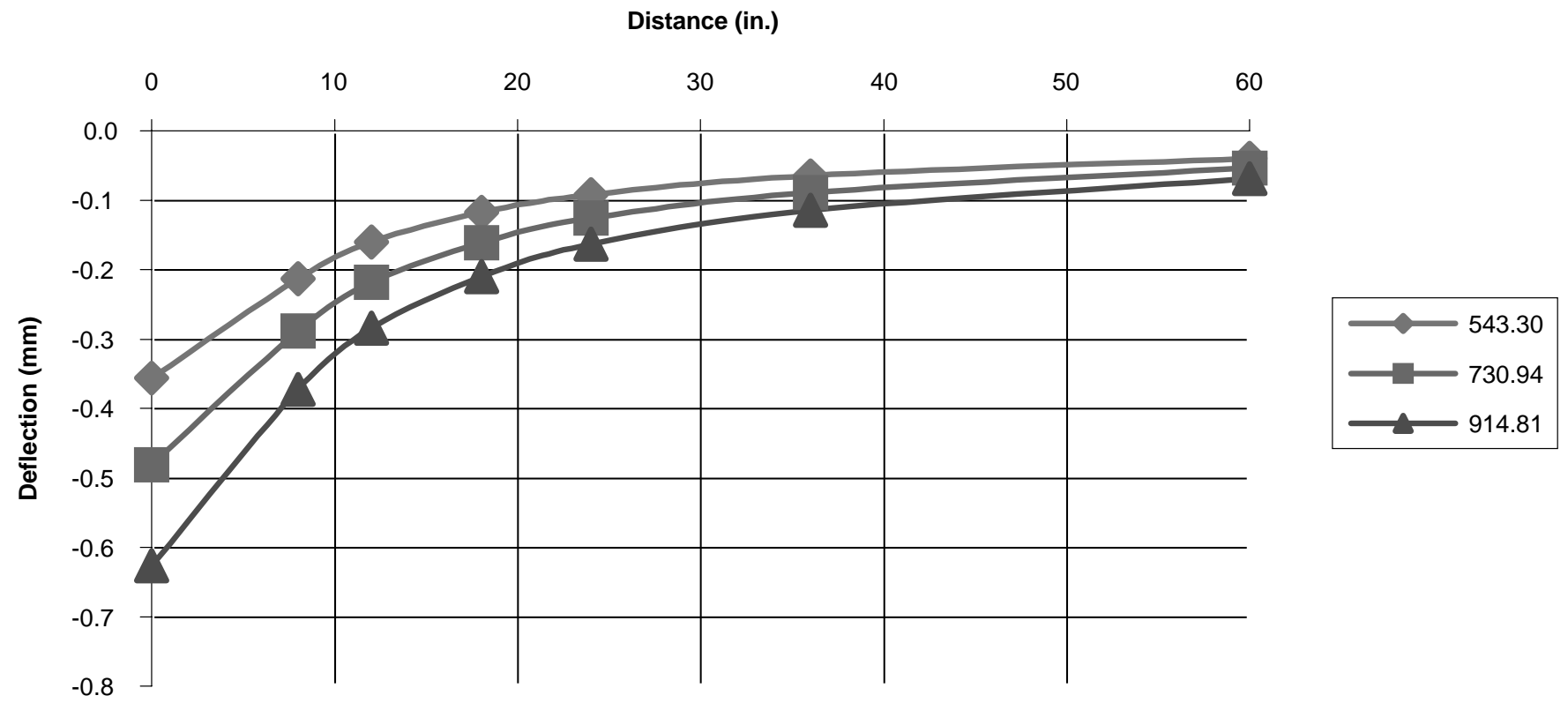

FIGURE 6 Average deflections for a 10.5-in. limerock layer, Section 3.

(80-kN) single-axle load. Therefore, it was necessary to convert the repetitions administered by the $22 \mathrm{kips}(98 \mathrm{kN})$ to an equivalent amount of repetitions produced by the standard 18-kip $(80-\mathrm{kN})$ equivalent single-axle load (ESAL) as specified by AASHTO for a standard truck. A 22-kip (98-kN) ESAL $_{18}$ is defined by Equations 3 and 4.

$\mathrm{EALF}=\left[L_{x} / 18\right]^{4.02}$

$\mathrm{ESAL}_{18}=N_{22} \times \mathrm{EALF}$

where

$\mathrm{EALF}=$ equivalent axle load factor,

$L_{x}=22-$ kip $(98-\mathrm{kN})$ single-axle load,

$N_{22}=$ numbers of passes of the 22-kip (98-kN) load repetitions applied at the test track, and

$\mathrm{ESAL}_{18}=$ numbers of 18-kip $(80-\mathrm{kN})$ loads corresponding to $N_{22}$.

The sum of the repetitions successfully completed at UCF-CATT can be used to equate the tested paving materials' simulated life expectancy if it were applied to normal highway conditions. As an example, hypothetically take an average daily traffic volume of 7,500 in one direction for typical medium-heavy highway traffic with an average $6 \%$ of an 18-kip $(80-\mathrm{kN})$ truck. The annual volume of heavy trucks can be calculated as follows:

$\mathrm{AHTT}=\mathrm{ADT} \times T \times L \times 365$ days

where

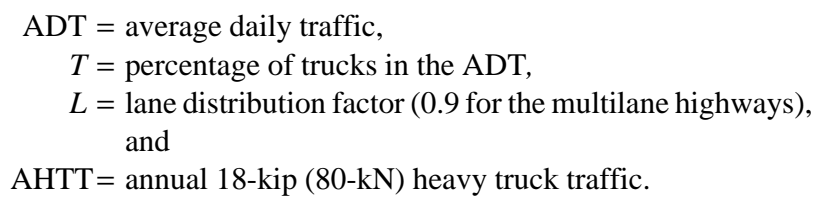

Equation 6 equates the test track results to a simulated 1-year life expectancy:

$\mathrm{AHTT}=N \times \mathrm{EALF} \times P$

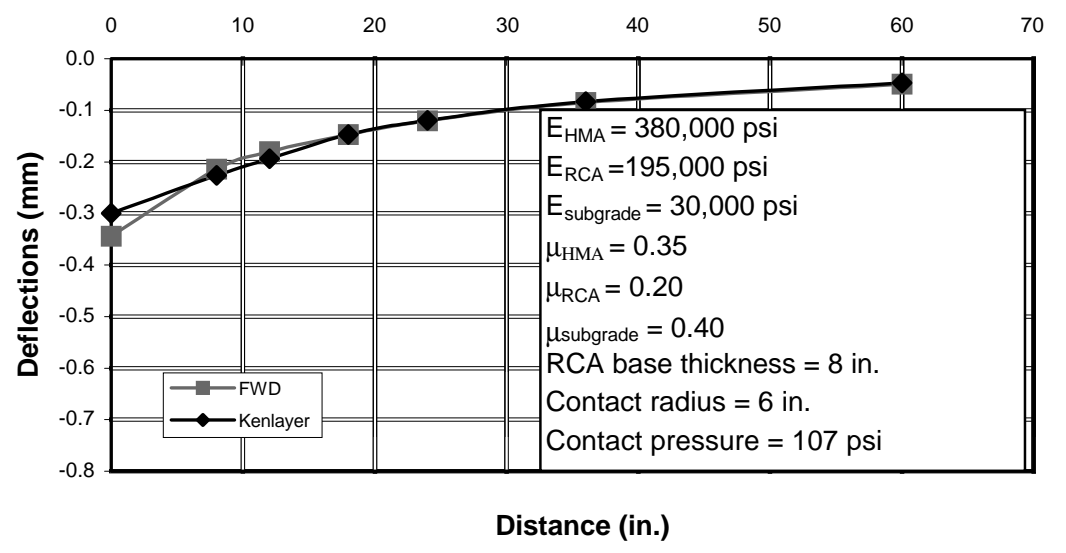

FIGURE 7 Comparison of KENLAYER and FWD at a contact pressure of $734 \mathrm{kPa}$. 
where

$N=$ number of 22-kip $(98-\mathrm{kN})$ load repetitions required per year,

$\mathrm{EALF}=$ equivalent axle load factor (Equation 3),

AHTT = annual 18-kip (80-kN) heavy truck traffic (Equation 5), and

$P=$ probability of occurrence $=3$.

The simulated life expectancy (SLE) of the test sections can then be calculated using Equation 7:

$\mathrm{SLE}=\mathrm{ESAL}_{18} / N$

Applying the foregoing equations and the data collected at UCFCATT, the computed values from Equations 3 through 7 are obtained and shown in Table 5.

\section{Rutting Measurement from Pavement Sections}

To determine if the base course has caused any rutting at the completion of the performance test, a strip $12 \mathrm{in} .(30 \mathrm{~cm})$ wide and $10 \mathrm{in}$. $(25 \mathrm{~cm})$ deep was saw cut from each test section and removed from the track. By carefully examining and measuring the cross-sectional profile and the cut sections, it was concluded that no significant rutting occurred on any base materials in this project.

\section{STRUCTURAL LAYER COEFFICIENTS AND THICKNESS DESIGN}

The resilient moduli of test sections determined from this study were converted into the corresponding structural layer coefficients for the asphalt concrete, $a_{1}$, RCA, $a_{2 \mathrm{RCA}}$, and limerock, $a_{2 \mathrm{LR}}$, which are, respectively, $a_{1}=0.42, a_{2 \mathrm{RCA}}=0.34$, and $a_{2 \mathrm{LR}}=0.213$.

If a conservative structural number of 3.0 is used for the design of well-drained base course thickness, the thickness of RCA base course required would be not more than $4.0 \mathrm{in}$. $(10.2 \mathrm{~cm})$, whereas the limerock base course required would be less than $6.5 \mathrm{in}$. $(16.5 \mathrm{~cm})$. A minimum thickness of 6-in. (15.2-cm) RCA base course is recommended as a conservative consideration.

From the layer coefficients of RCA and limerock, the thickness equivalency of RCA to limerock can be estimated as

$H_{\mathrm{RCA}}=(0.34 / 0.213) H_{\mathrm{LR}}=1.6 H_{\mathrm{LR}}$.

This means that 1 in. $(2.54 \mathrm{~cm})$ of RCA will be equivalent to $1.6 \mathrm{in}$. $(4.0 \mathrm{~cm})$ of limerock.

TABLE 5 Simulated Life Expectancy Analysis

\begin{tabular}{|c|c|c|}
\hline VARIABLE & EQUATION & OUTPUT \\
\hline EALF & 3 & 2.24 \\
\hline ESAL $_{18}$ & 4 & 811,324 Repetitions \\
\hline AHTT & 5 & 147,825 Trucks \\
\hline N & 6 & 21,998 Repetitions \\
\hline SLE & 7 & 36.9 Years \\
\hline
\end{tabular}

\section{SUMMARY AND CONCLUSIONS}

To successfully use the recycled concrete materials in flexible pavement construction, it is necessary to develop a set of Florida DOT guidelines and specifications. To accomplish this objective, a literature review of previous work was completed. Laboratory tests on physical and mechanical properties of RCA including gradation, LBR, LA abrasion loss, surface soundness, sand equivalent, heavy metal, optimum moisture content and maximum dry density, hydraulic conductivity, and impurities were conducted. A list of guidelines is established, and proposed specifications for the use of RCA based on the test methods and the limits of test results is presented in Table 6.

In addition to the laboratory tests, RCA and LR test sections were constructed at UCF-CATT for the performance test of base courses within the flexible pavement system. A total of 362,198 load repetitions were applied to the test sections. This would represent a pavement life expectancy of over 36 years based on the same level of traffic conditions. The pavement distresses of rutting, cracking, and settlement were closely monitored during the performance testing. No surface rutting was measured in any of the test sections. Many transverse cracks and one longitudinal crack occurred on the limerock section, and no cracks were observed in either RCA test section.

Before the accelerated performance test, an FWD test was conducted on the test sections. The in situ moduli of RCA, LR, and subgrade were backcalculated by using the FWD deflection data and KENLAYER computer program. Subsequently, the tensile strain at the bottom of the surface course and the compressive strain at the top of the subgrade were computed, and the allowable load repetitions to the fatigue and rutting failures of the pavement system were determined. The allowable load repetitions for RCA test sections appear to be very high as neither RCA test section failed in fatigue and rutting.

In conclusion, the results of this study show that pavement sections built with RCA base demonstrated a better performance than the pavement section built with the limerock base.

\section{GUIDELINES AND SPECIFICATIONS}

\section{Guidelines}

RCA producers should provide some or all of the data required by the following standard tests:

- Gradation test,

- LBR test,

- LA abrasion loss test,

- Sodium sulfate soundness test,

- Sand equivalent test,

- Heavy metals test,

- Optimum moisture content and maximum dry unit weight test,

- Permeability test,

- Impurities test, and

- Material characterization (resilient modulus) test.

\section{Specifications}

A summary of the proposed specifications for the selection and use of RCA as a base course in flexible pavements based on the results of this study is presented in Table 6 . 
TABLE 6 Proposed RCA Specifications

\begin{tabular}{|c|c|c|c|}
\hline Type of Test & Average Test Results & Proposed Specifications & $\begin{array}{c}\text { FDOT } \\
\text { Specifications } \\
\end{array}$ \\
\hline $\begin{array}{l}\text { Gradation Test } \\
\text { (FM 1-T 027) }\end{array}$ & Average Gradation & $\begin{array}{l}\text { Gradation Limits } \\
\text { (90\% Confidence } \\
\text { Interval) }\end{array}$ & Section 204 \\
\hline Sieve No. & & --- & --- \\
\hline $50 \mathrm{~mm}$ & 100.0 & Min. 100 - Max. 100 & Min. 100 - Max. 100 \\
\hline $37.5 \mathrm{~mm}$ & 99.5 & Min. 98 - Max. 100 & Min. 95 - Max. 100 \\
\hline $19 \mathrm{~mm}$ & 83.2 & Min. 65 - Max. 100 & Min. 65 - Max. 90 \\
\hline $9.5 \mathrm{~mm}$ & 61.2 & Min. 40 - Max. 83 & Min. 45 - Max. 75 \\
\hline & 44.8 & Min. 27 - Max. 63 & Min. 35 - Max. 65 \\
\hline \# 10 & 34.4 & Min. 20 - Max. 49 & Min. 25 - Max. 45 \\
\hline \# $\mathbf{5 0}$ & 15.7 & Min. 8 - Max. 24 & Min. 5 - Max. 25 \\
\hline$\# \mathbf{2 0 0}$ & 3.8 & Min. 2 - Max. 6 & Min. 0 - Max. 10 \\
\hline \multirow{2}{*}{ LBR Test (FM - 515) } & & Test Average & Section 204 \\
\hline & 181.71 & Min. 120 & 100 \\
\hline \multirow{2}{*}{$\begin{array}{l}\text { LA Abrasion Loss } \\
\text { (FM } 1 \text { - T096) }\end{array}$} & & $\mathbf{9 0 \%}$ Confidence Interval & Section 204 \\
\hline & $44.02 \%$ & $<48 \%$ & $<45$ \\
\hline $\begin{array}{l}\text { Sodium Sulfate Test } \\
\text { (AASHTO T - 104) }\end{array}$ & $52 \%$ & $<50 \%$ & $15 \%$ \\
\hline $\begin{array}{l}\text { Sand Equivalent } \\
\text { (AASHTO T - 176) }\end{array}$ & $70.5 \%$ & $>70 \%$ & $\geq 28 \%$ \\
\hline Heavy Metals (EPA - 96) & $0-12 \mathrm{ppm}$ & $5 \mathrm{ppm}$ & $5 \mathrm{ppm}$ \\
\hline Asbestos (EPA - 89) & Free of Asbestos & Free of Asbestos & Section 112 EPA \\
\hline \multirow{2}{*}{$\begin{array}{l}\text { Optimum Moisture } \\
\text { Content (FM } 5 \text { - 521) }\end{array}$} & & $\mathbf{9 0 \%}$ Confidence Interval & See Section 200-6.4 \\
\hline & $11.2 \%-12.1 \%$ & $10 \%-12 \%$ & No Proper Values \\
\hline \multirow{2}{*}{$\begin{array}{l}\text { Maximum Dry Unit } \\
\text { Weight (FM } 5 \text { - 521) }\end{array}$} & & $\mathbf{9 0 \%}$ Confidence Interval & Limerock \\
\hline & $113.8 \mathrm{lb} / \mathrm{ft}^{3}-114.8 \mathrm{lb} / \mathrm{ft}^{3}$ & $108 \mathrm{lb} / \mathrm{ft}^{3}-120 \mathrm{lb} / \mathrm{ft}^{3}$ & $98 \%$ of Max. Dry Density \\
\hline Permeability (FM 5 - 513) & 0.72 (ft/day) & 0.10 to $1.40(\mathrm{ft} / \mathrm{day})$ & No Proper Values \\
\hline Impurities (FM $1 \mathrm{~T}$ - 194) & $1.99 \%$ by weight & $<2.0 \%$ by weight & $\begin{array}{l}\text { Substantially Free of } \\
\text { Impurities }\end{array}$ \\
\hline Structural Coefficient & 0.34 & 0.30 & 0.15 \\
\hline Thickness Requirement & 4 in. $(10.2 \mathrm{~cm})$ & Min. 8.0 in. $(20.4$ cm $)$ & Min. 8.0 in. $(20.4 \mathrm{~cm})$ \\
\hline Thickness Equivalency & $0.34(\mathrm{RCA}) / 0.213$ (LR) & 1.0 in. $(2.54 \mathrm{~cm})$ & 1.6 in. $(4.0 \mathrm{~cm})$ \\
\hline
\end{tabular}

FM indicates Florida test method number.

\section{ACKNOWLEDGMENTS}

This research study was sponsored by the State Materials Office of the Florida Department of Transportation.

\section{REFERENCES}

1. Chan, C. The Problem with Waste Concrete and the Need for Its Recycling. Website of Department of Civil Engineering, University of British Columbia, Vancouver, Canada, 2001.

2. User Guidelines for Waste and Byproduct Materials in Pavement Construction. FHWA-RD-97-148. FHWA, Department of Transportation, 1997.

3. Chini, A., and S. Kuo. Guidelines and Specifications for the Use of Reclaimed Aggregates in Pavement. Report No. BA509. Florida Department of Transportation, Gainesville, 1998.

4. Management of Construction and Demolition Waste. OG ENV.E.3. European Commission Directorate-General Environment, 2000.
5. Collins, R. J. Reuse of Demolition Materials in Relation to Specifications in the UK. In Demolition and Reuse of Concrete and Masonry (E. K. Lauritzen, ed.), E \& FN Spon, London, 1994, pp. 49-56.

6. Kasai, Y. Guidelines and the Present State of the Reuse of Demolished Concrete in Japan. In Demolition and Reuse of Concrete and Masonry (E. K. Lauritzen, ed.), E \& FN Spon, London, 1994, pp. 93-104.

7. Protocol for Conducting Environmental Compliance Audits at Facilities with PCBs, Asbestos, and Lead-Based Paint Regulated Under TSCA, Appendix E. EPA 300-B-00-004. Environmental Protection Agency, 2000.

8. Senior, S. New Development in Specification for Road Base Materials in Ontario. Proc., 45th Canadian Geotechnical Conference, Canadian Geotechnical Society, 1992, pp. 99-1-99-9.

9. Huang, Y. H. Pavement Analysis and Design. Prentice Hall, Englewood Cliffs, N.J., 1993.

10. Crans, J. R., et al. Fatigue Behavior of Thin Asphalt Concrete Layers in Flexible Permanent Structures. Proc., Association of Asphalt Paving Technologists, Vol. 53, 1984, pp. 559-582.

Publication of this paper sponsored by Committee on Mineral Aggregates. 